\title{
TEACHER'S PERSPECTIVE : ENGLISH IN ELEMENTARY SCHOOL, IS IT NECESSARY OR NOT?
}

\author{
Titin Kustini \\ English Language Education Program, Universitas Majalengka \\ titinkustini@unma.ac.id
}

\begin{abstract}
The Covid 19 pandemic which requires online learning has caused learning difficulties for students at the junior high school level, especially in English subjects which they have only formally get because in elementary school there are no more English lessons. Especially in rural areas where students' insight is very limited and parents' ability to assist their children in learning is also quite limited, it is become a big problem. English is really a new thing that they get, while with face-to-face learning, they lost opportunities to ask and discuss learning difficulties to their teacher. This study aims to find out how the perspective of elementary school teachers on English lessons, whether they consider it necessary or not if English is taught since elementary school related to a lot of students find difficulties to learn English in junior high school. 9 teachers participated in this research. They are spread evenly in various places in Majalengka district. Data were obtained through observation, questionnaires and interviews by google form and whatsapp and analyzed by qualitative. The results of the study finds that $100 \%$ of the teachers agreed English should taught in elementary schools. The obstacles might be faced if English is applied in elementary schools, 55,5 $\%$ said facilities and infrastructure, $22,2 \%$ said nothing and $11,1 \%$ students' interest in learning english and $11,1 \%$ said that they don't have English teacher. And their expectations are students able to speak in daily conversation $(22,2 \%)$ and $77,8 \%$ hope students know basic english to make them easier in learning English at the next level.
\end{abstract}

Keywords: Teacher, perspective, english, elementary

\section{Introduction}

Officially, the policy to include English lessons in elementary schools is in accordance with the policy of the Ministry of Education and Culture of the Republic of Indonesia (Depdikbud RI) No. 0487/1992, Chapter VIII which states that elementary school can add subjects in its curriculum as long as the lessons do not conflict with the goals of national education. In this case, the school has the authority to include English lessons based on the considerations and needs of the situation. This policy has a positive impact, namely that many schools participate in implementing English language teaching programs starting from elementary school, although there are problems that cannot be ruled out, namely the quality and readiness of English teachers in elementary schools.

Meanwhile, Hapsari (2012) stated that teaching English for elementary school students is based on the Decree of the Minister of Education and Culture No. 060/U/1993 dated February 25 regarding the possibility of English language programs as a local content subject for elementary school, and can start in grade 4 elementary school (Depdiknas). ). This policy was taken because of the need to participate in the era of globalization. In its development, English, which was originally an elective local content subject, became mandatory local content in several regions. Furthermore, English lessons were initially started in grade 4 elementary school, starting in grades 1, 2 and 3.

But actually, English in elementary school has not been officially included in the curriculum. 
The curriculum in Indonesia itself has undergone several changes/improvements. There are several curriculum models that have been used in Indonesia, namely: Leer Plan (Lesson Plan) in 1947, Unraveled Lesson Plans in 1952, Education Plans in 1964, Curriculum 1968, Curriculum 1975, Curriculum 1984, Curriculum 1994, Curriculum 1999, Competency-Based Curriculum ( KBK) in 2004 and the Education Unit Level Curriculum (KTSP) in 2006. The curriculum that has just been used in the 2014/2015 academic year is the 2013 curriculum. From the above curricula, English has been taught in elementary schools since 1994, but it is still a local content side by side with several other subjects which are also used as local content (Mulok). However, learning English in elementary school is quite encouraging.

Unfortunately, when the 2013 curriculum (Kurtilas) was implemented, English was removed from local content on the grounds that students in elementary school would be further strengthened in Indonesian and regional languages. It is feared that if English is still included as a local content lesson, it will become a burden for elementary students. Of course it is quite confusing for students as well as teachers. On the other hand, all are aware of the importance of learning English in primary schools as the basis for learning in secondary schools.

In Kurtilas, English is seen by the government as a lesson that may or may not exist. So more put into extra curricular. Thus, English is not taught in all schools. There are those who still teach it even though with extra-curricular status, but many of them don't teach it at all.

The problem is rising when the Covid-19 pandemi when face to face learning moved to study from home, many students have big problem in learning English in junior high school because of never got basic English in elementary school.

This study aims to reveal the perspective of elementary school teachers on learning English in elementary school, as well as to measure the extent to which elementary school conditions in the implementation of English learning if English is applied in elementary school. And also the expectation to student's achievement if English taught in elementary school.

\section{Research Methoodology}

This study employed a questionnare survey distributed to some elementary school teacher by google form that they spread in Majalengka regency and also observation and interview by WhatsApp. The questionnaire was developed by the researcher. It consists of six open questions asking about the respondent's opinion on English, is it necessary or not to taught in elementary school, human resources in their school relate ability to teach english, obstacles if english taught in their school, and also their expectation about output of English lesson in elementary school.

\section{Findings and Discussion}

The data of teachers' perspective on english lesson in elementary school are reflected in situation in their school relate to english lesson, their point of view to the necessities of english lesson taught in elementary school, human resources, obstacles and their hope to english lesson when it taught in elementary school.

All respondents said that it is important English to be taught in elementary school (100\%).

Picture 1. Teacher's perspective on English to be taught in elementary school

And their situation in school, 66,7\% said that there's english teachers in their school and just $33,3 \%$ which don't have english teachers.

Picture 2. English teacher in elementary school 
To answer the fourth question about what needs to be prepared regarding human resources and infrastructure, $11,1 \%$ said nothing, 22,2\% said need training, learning media, invite native speaker and providing language lab, 55,5\% need learning media and lesson books, and $11,1 \%$ said need both learning media and competence teacher.

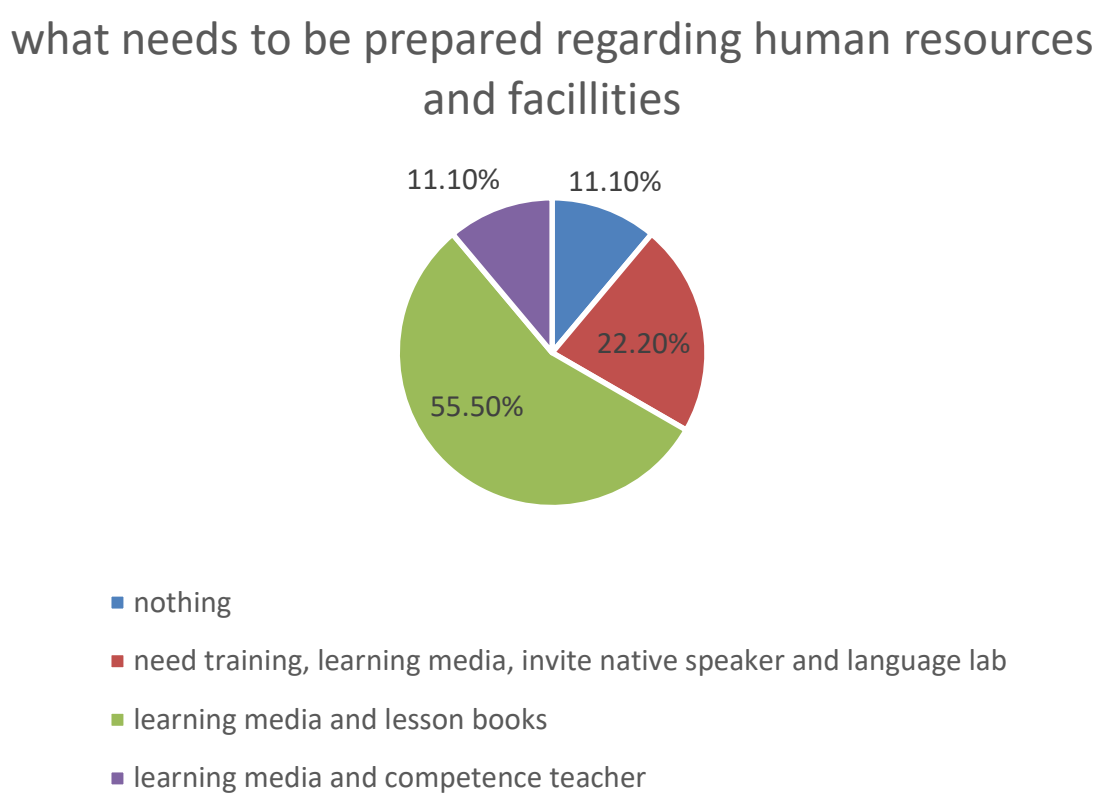

Picture 3. School needs regarding human resources and facilities

In accordance with obstacles might be faced if English is applied in elementary schools, 55,5 $\%$ said facilities and infrastructure, $22,2 \%$ said nothing and $11,1 \%$ students' interest in learning english and $11,1 \%$ said that they don't have english teacher.

\section{obstacles in elementary school}

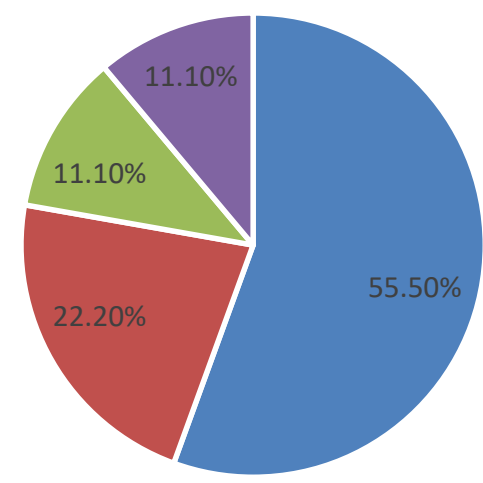

- facilities and infrastructures a nothing

m students' interest in learning english = they don't have english teacher

Picture 4. Obstacles in elementary school

The expectations of teachers about the targets/achievements that must be achieved by learning English in elementary school, 77,8\% said students know basic english to make them easier in learning english at the next level and 22,2\% hope students able to speak in daily conversation. 


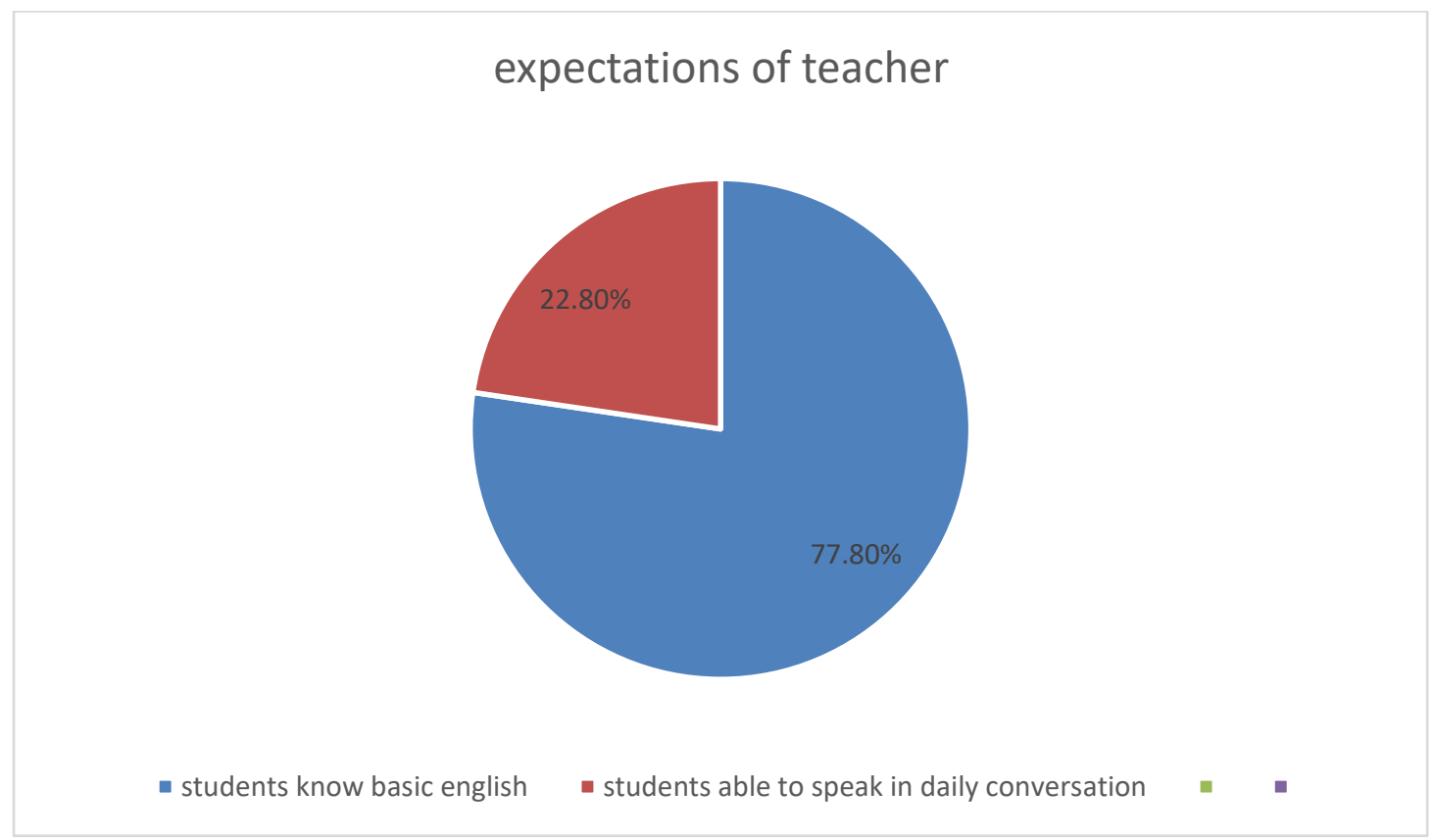

Picture 5. Expectations of teacher

\section{Conclusion}

The results of the analysis aiming to answer research questions can be summarized into three points. First, all of teachers agreed that english is very important to be taught in elementary school. Second, they still have obstacles when English taught in elementary school relate to facilities and infrastructure. Third, their expectation are students able to speak in daily conversation and students know English basic to make them easier learning English in the next level.

\section{References}

Cameron, Lynne. (2001). Teaching language to young learners. The Edinburgh Building. Cambridge, New York; Cambidge University Press.

Cuningham, Patrici M and Arthur/Heilman. 1981. Phonich they use: Words for the reading and writing. Harper Collins.

Depdikbud. (1995) BPP. Muatan lokal sekolah dasar mata pelajaran bahasa Inggris. Semarang; Pustaka Baru.

Harmer, J. 1.(983). The practice of English language teaching. London: William Cloves Limited, Beccles and London.

Haris, David P. 169. Testing English as a second language. United States os America: Mc. Grow Hill Inc. 
Johnson, Jeffrey.C. (1990). Selecting ethnographic informants. Qualitative research series v. 22.

SAGE UK.

Klimova Blanka Frydrychova (2013) Teaching English to pre-school children: Third World Conference on Learning, Teaching and Educational Leadership WCLTA 2012 .

Noss, Richard, B. (1984). An overview of language issues in outh-East Asia 1950-190. OUP, Singapore.

Noss, Richard B (P.W.J Nababan). (1984). Language teaching issues in multilingual environments in Souteast Asia. Singapore: SEAMO. Regional Language Center.

Richards, Jack C. (2001). Curriculum development in language teaching. United States of America. Cambridge University Press.

Sear Foss, Lyndon and John E Readance. (1985). Helping children learn to read. New Jersey: Prentice Hall, Inc.

Sutarsyah, Cucu. (2014) Pembelajaran bahasa Inggris sebagai muatan lokal pada sekolah dasar di propinsi Lampung. Jurusan bahasa dan seni FKIP Universitas Lampung. Unpublished Thesis. 